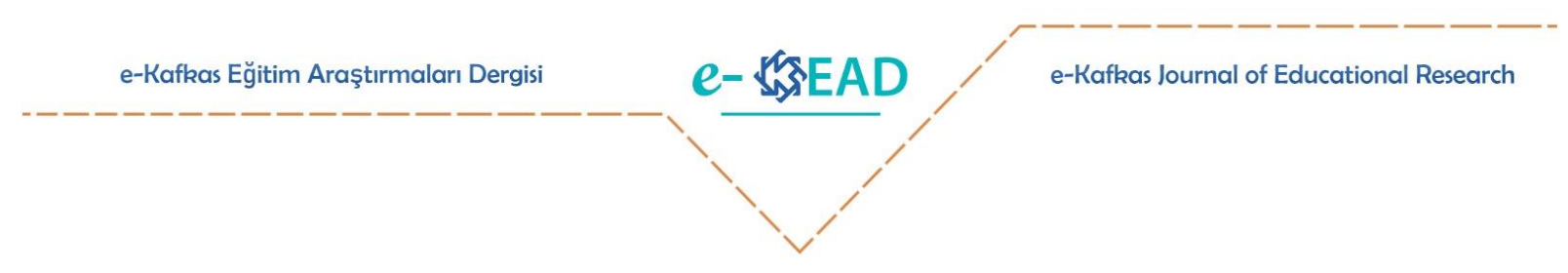

\title{
Examination of a Middle School Mathematics Preservice Teacher's Interpretation Skills ${ }^{1}$
}

\section{Ebru Ersarı ${ }^{2}$}

\section{To cite this article:}

Ersar1, E. (2021). Examination of a middle school mathematics preservice teacher's interpretation skills. e- Kafkas Eğitim Araştırmaları Dergisi, 8, 413-437. doi:10.30900/kafkasegt.959043

\section{Research article}

Received: 28.06 .2021

Accepted:31.08.2021

\begin{abstract}
This study aims to explore one preservice teacher's interpretation of student mathematical thinking using pattern recognition and linear function tasks. Specifically, the research question for this study was as follows: How does a preservice middle grade mathematics teacher interpret student mathematical thinking using tasks designed to test students' pattern recognition and linear function abilities? The preservice teacher, Amy, was a middle school preservice teacher from the Mathematics and Science Education Department of a major land-grant university in the southeastern Unites States. The data consists of Amy's responses during a face-to-face, semi-structured interview, written work she produced during the interview, and a careful analysis of a transcript of the interview. With regards to interpreting important mathematical ideas in students' work in the National Council of Teachers of Mathematics [NCTM] videos, this study found that the preservice teacher provided explanations of specific important mathematical ideas and their meaning. When the preservice teacher interpreted students' mistakes or misconceptions, she explained the misconceptions mathematically rather than providing specific examples from the video. In terms of interpreting the similarities between students' reasoning, the preservice teacher's description of the similarities between students' reasoning was broad. Depending on the task and how many times she watched the videos, either one or two times, the extent to which she provided evidence varied when she interpreted the differences between students' reasoning. This study revealed that the strength of the preservice teacher's interpretation strategies varied depending on the tasks. The preservice teacher did not provide detailed explanations of students' reasonings when watching NCTM videos even though she solved all the tasks in multiple ways and explained the key concepts while solving the problems.
\end{abstract}

Keywords: Professional noticing, interpreting, preservice teacher education, mathematics education

\footnotetext{
${ }^{1}$ This study is part of the author's dissertation study titled "Exploration of Three Domains: Specialized Content Knowledge, Knowledge of Content and Students, and Interpretation Strategies of Preservice Teachers." approved by the University of Georgia.

2 (D) Corresponding Author, Research Assistant, ebru.ersari@balikesir.edu.tr, Balıkesir University, Necatibey Faculty of Education, Turkey
} 


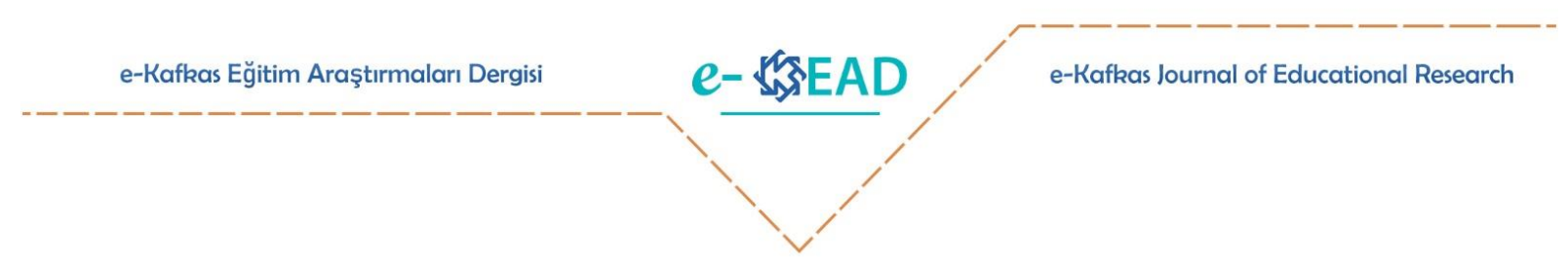

\title{
Bir Ortaokul Matematik Öğretmen Adayının Yorumlama Becerilerinin İncelenmesi ${ }^{1}$ Ebru Ersarı ${ }^{2}$
}

\begin{abstract}
Atıf:
Ersar1, E. (2021). Examination of a middle school mathematics preservice teacher's interpretation skills. e- Kafkas Eğitim Araştırmaları Dergisi, 8, 413-437. doi:10.30900/kafkasegt.959043
\end{abstract}

Araştırma Makalesi

Geliş Tarihi: 28.06 .2021

Kabul Tarihi:31.08.2021

\section{$\ddot{O} z$}

$\mathrm{Bu}$ çalışmanın amacı, bir öğretmen adayının, örüntü tanıma ve doğrusal fonksiyon görevlerini kullanarak öğrencilerin matematiksel düşüncelerini yorumlamasını incelemektir. Spesifik olarak, bu çalışma için araştırma sorusu şu şekildedir: Bir ortaokul matematik öğretmeni adayı, öğrencilerin örüntü tanıma ve doğrusal fonksiyon yeteneklerini test etmek için tasarlanmış görevleri kullanarak öğrencilerin matematiksel düşünmesini nasıl yorumlar? Öğretmen adayı Amy, Amerika Birleşik Devletleri'nin güneydoğusundaki büyük bir üniversitenin Matematik ve Fen Eğitimi Bölümü'nden bir ortaokul öğretmen adayıydı. Veriler, Amy'nin yüz yüze, yarı yapılandırılmış görüşme sırasında verdiği yanıtlar ve görüşme sırasında ürettiği yazılı çalışma ile görüşmenin transkriptinden oluşmaktadır. Bu çalışma, NCTM videolarındaki öğrencilerin çalışmalarında yer alan önemli matematiksel fikirlerin yorumlanması açısından, öğretmen adayının spesifik önemli matematiksel fikirleri ve onların anlamlarını açıkladığını tespit etmiştir. Öğretmen adayı öğrencilerin hatalarını veya kavram yanılgılarını yorumlarken videodan belirli örnekler vermekten ziyade kavram yanılgılarını matematiksel olarak açıklamıştır. Öğrencilerin akıl yürütmeleri arasındaki benzerlikleri yorumlama açısından, öğretmen adayının öğrencilerin akıl yürütmeleri arasındaki benzerliklere ilişkin açıklaması yüzeysel olmuştur. Göreve ve videoları kaç kez, bir veya iki kez, izlediğine bağlı olarak, öğretmen adayının öğrencilerin akıl yürütmeleri arasındaki farklılıkları yorumlarken kanıt sunma derecesi çeşitlilik gösterdi. Bu çalışma, öğretmen adayının yorumlama stratejilerinin gücünün görevlere bağlı olarak değiştiğini ortaya koymuştur. Öğretmen adayı tüm görevleri birden fazla şekilde çözmüş ve problemleri çözerken anahtar kavramları açıklamış olmasına rağmen derinlemesine yorumlama stratejileri sağlamamıştır.

Anahtar Sözcükler: Profesyonel farkındalık, yorumlama şablon, öğretmen adayı eğitim, matematik eğitimi

\footnotetext{
${ }^{1} \mathrm{Bu}$ çalışma, yazarın Georgia Üniversitesi tarafından onaylanmış doktora çalışmasından üretilmiştir.

2 (iD) Sorumlu yazar, Araştırma Görevlisi Doktor, ebru.ersari@balikesir.edu.tr, Balıkesir Üniversitesi, Necatibey Eğitim Fakültesi, Türkiye
} 


\section{Introduction}

How well can teachers incorporate their knowledge into their instruction to help improve students' learning? How powerful are teachers to comprehend students reasoning abilities? How effective are teachers at noticing? These are some core questions each mathematics teacher needs to ask themselves. Addressing students' reasoning abilities goes back to cognitive skills teachers need to both recognize how students are interacting with the material to be learned and how they can modify their teaching methods to work within those learning habits or patterns students have developed or adopted. Therefore, these complex and crucial questions need to be investigated further by mathematics education researchers. Mason (2002) focused on the concept of noticing as an intentional act, and he described the discipline of noticing as a set of techniques for pre-paring and post-paring (Mason, 2011). Pre-paring refers to noticing at the present time, and post-paring refers to thinking back to the recent past and selecting specific parts to notice (Mason, 2011). To pare is to "notice in the moment and be able to act freshly rather than habitually" (Mason, 2011, p. 38). The dynamic aspect of a classroom necessitates that teachers notice many aspects of students' behaviors such as their cognitive habits, cultural influences, and ideological positions (Louie, 2018). Professional noticing, therefore, requires evaluating in the teaching moment. As a result, professional noticing helps researchers understand the relationship between past experiences, present teaching, and possible future strategies to improve teaching. Considering the complexity of noticing as a process, professional noticing consists of identifying students' ideas, evaluating student thinking, and then responding effectively to the students (Campbell, 2018).

Specific to professional noticing in the profession of teaching, Jacobs, Lamb, and Philipp (2010) divided professional noticing into three skills: attending, interpreting, and decision making. They conducted their cross-sectional study with 131 preservice and practicing teachers. They provided professional development in their study and utilized two written measures to measure the participants' noticing skills. Jacobs et al.'s (2010) study concerning the attending skill explored what teachers considered noteworthy in student mathematical thinking. In their study, the interpreting skill focused on how teachers' interpretations were consistent with specific students reasoning methods. This skill also explored the consistency between teachers' interpretations and students' development of mathematical thinking. They defined three types of evidence of the interpreting student thinking: robust, limited, and lack of evidence. Regarding the decision-making skill, how teachers react to student mathematical thinking and the reasoning behind the students' reactions was explored (Jacobs et al., 2010). They found that professional noticing could be learned, and both teaching experience and professional development could help teachers improve their noticing skills. Because it occupies the middle ground between the attending (Schack, Fisher, Thomas, Eisenhardt, Tassell, Yoder, 2013; Santagata \& Yeh, 2016) and decision-making (Dyer \& Sherin, 2016) skills, the interpreting skill has the potential to impact both of these skills. Since pre-service teachers' attention strategies are not yet sufficiently developed (Star \& Strickland, 2008), and they do not have the opportunity to be involved in the decision-making process in actual classrooms, it is reasonable to focus on the interpretation phase. Also, studies show that improving teachers' interpretation skills is related to the improvement of their teaching skills (Dyer \& Sherin, 2016; Jacobs \& Empson, 2016). In their study, Dyer and Sherin (2016) explored two secondary mathematics teachers' interpreting strategies. Those two teachers provided what they considered important in their teaching right after their instruction. They described three kinds of instructional reasoning about interpreting students mathematical thinking: a) connecting various explicit moments of student thinking, b) recognizing the connection between student mathematical thinking and the form of the mathematical tasks, and c) developing tests related to student thinking. Dyer and Sherin (2016) stated that those three strategies were linked to responsive teaching.

Professional noticing is relatively a new area of research in mathematics education, and little is known about the components of interpreting skill. Even though the interpretation skill plays an important role in effective teaching, there needs to be greater research performed focusing on the meaning of the interpretation skill and its constituents (Sánchez-Matamoros, Fernández, \& Llinares, 2019; Ulusoy \& Çakıroğlu, 2020). Thus, the aim of this study is to elaborate further on the interpretation skill of a preservice teacher. 


\section{Preservice Teachers' Interpretations of Student Mathematical Reasoning}

The literature (e.g., Didis, Erbas, Cetinkaya, Cakiroglu, and Alacaci, 2016; Simpson \& Haltiwanger, 2017; Phelps-Gregory \& Spitzer, 2018; Dindyal, Schack, Choy, \& Sherin, 2021) which focuses on preservice teachers' interpretations of student mathematical reasoning, consists of the themes as follows:

(1) aspects of student mathematical reasoning that were explored/interpreted by preservice teachers

(2) limitations of preservice teachers' interpretations of student mathematical reasoning and on the challenges preservice teachers faced when making such interpretations.

A growing body of research on professional noticing strategies given below focused on teachers' noticing of student mathematical reasoning. Most of these studies were intervention studies that explore how a particular intervention helped pre-service and in-service teachers improve their strategic noticing skills. Interventions may include any of the following:

a) Training as instruction modules (Krupa, Huey, Lesseig, Casey, \& Monson, 2017; Fisher, Thomas, Schack, Jong, \& Tassell, 2018; Smith, Beattie, Ren, \& Heaton, 2020),

b) Clinical interviews (van den Kieboom, Magiera, \& Moyer, 2017; Shin, 2021),

c) Coding transcripts (Scherrer \& Stein, 2013; Mitchell \& Marin, 2015), and

d) Formative intervention (Tunney \& van Es, 2016).

Regarding the impact of intervention, and intervention studies focusing on the interpretation strategies of preservice mathematics teachers, it was consistently found that these strategies could be improved. Moreover, regarding the types of intervention used (Stahnke, Schueler, \& Roesken-Winter, 2016), studies exploring professional noticing relied either on students' written work (Jakobsen, Ribeiro, \& Mellone, 2014), observational videos (Kersting, 2008; Norton, McCloskey, \& Hudson, 2011; König, Blömeke, Klein, Suhl, Busse, \& Kaiser, 2014; Knievel, Lindmeier, Heinze, 2015; Osmanoglu, Isiksal, \& Koc, 2015; Schäfer \& Seidel, 2015), or both (Kilic, 2018). In summary, most of the studies exploring preservice teachers' interpretation of student mathematical reasoning used students' written work. However, they did not provide abundant information about the process of students' reasoning owing the fact that preservice teachers see only the finished product when relying on such data.

In studies exploring preservice teachers' interpretations of student mathematical reasoning through video analysis, preservice teachers had greater opportunities than through students' written work to analyze student mathematical reasoning processes. Advantageously they could observe how students solve problems. However, the process might not accommodate student group work because the camera might not capture students' individual thought processes. However, if studies conduct one-onone interviews with students, they can capture students' thinking processes by focusing on individuals. The following themes explain preservice teachers' interpretation strategies:

\section{Aspects of Student Mathematical Reasoning That Were Explored/Interpreted by Preservice Teachers}

In the literature, some of the studies about the aspects of student mathematical reasoning have focused on specific content or a specific process (Dindyal et al., 2021) such as fractions (Dreher and Kuntze, 2015), proportional reasoning (Hines \& McMahon, 2005; Fernández, Llinares, \& Valls, 2013; Son, 2013), pattern generalization (Callejo \& Zapatera, 2017), modeling tasks (Didis et al., 2016), the derivative concept (Sánchez-Matamoros, Fernández, \& Llinares, 2015), decimals (Jong, Thomas, Fisher, Schack, Davis, Bickett, 2017), early numeracy (Schack et al., 2013), and the equal sign (van den Kieboom et al., 2017). Other studies have investigated the improvement of their interpretation strategies with different content over a period of time (Ingram, 2014; McDuffie, Foote, Bolson, Turner, Aguirre, Bartell, ...\& Land, 2014; Santagata \& Yeh, 2016; Ulusoy, 2016; Amador, Carter, Hudson, \& Galindo, 2017; Superfine, Fisher, Bragelman, Amador, 2017; Teuscher, Leatham, Peterson, 2017; PhelpsGregory \& Spitzer, 2018). 
These studies show that researchers explored preservice teachers' interpreting from a wide range of spectrum regarding the aspects of student mathematical reasoning. The content explored by the researchers also varied from early grades level to high school level. Since the focus of this study was a middle school preservice teacher's interpreting strategies, concerning the preservice teacher's familiarity with the grade level and the content, pattern recognition and linear function tasks were selected.

\section{Limitations of Preservice Teachers' Interpretations of Student Mathematical Reasoning and on the Challenges Preservice Teachers Face When Making such Interpretations}

The literature indicates that preservice teachers struggle when interpreting student mathematical reasoning (Jong et al., 2017; Krupa et al., 2017; Simpson \& Haltiwanger, 2017). Krupa et al. (2017), for example, found that secondary preservice teachers had insufficient interpretation skills both before and after the intervention. Researchers explored the extent to which preservice teachers were able to explain student mathematical understanding and challenges. The specificity of preservice teachers' explanations of students' procedural and conceptual understanding, as well as students' challenges, strengths, and weaknesses, were deemed to be important interpretation indicators. Krupa et al. (2017) designed a curricular module consisting of pre- and post-assessments, course readings and discussions, a secondary student's interview video, and a reflection paper. They found that most preservice teachers did not enhance their interpretation skills after the intervention.

Studies have also revealed that preservice teachers show poor abilities with regard to this interpretation skill. Further steps are required to bolster their skills (Didis et al., 2016). They need greater training as part of their education prior to entering the classroom to address this deficiency (Ingram, 2014). Also, further examination is needed to examine why preservice teachers have so much difficulty with this interpretation skill (Blömeke, Gustafsson \& Shavelson, 2015; Heinrichs and Kaiser, 2018) and what steps could be taken to address their lack of competency in this skill (Herppich et al., 2018).

This descriptive study aimed to explore one preservice teacher's existing interpreting skills in the context of student mathematical reasoning by using videos from actual classrooms. Therefore, no intervention or professional development was used. The purpose was to investigate the depth of her extant interpreting strategies. Also, the goal was to describe the weakness and the strength of her interpreting strategies. Therefore, the research question for this study was as follows: "How does a preservice middle grade mathematics teacher interpret student mathematical thinking using tasks designed to test students' pattern recognition and linear function abilities?"

\section{Methodology}

\section{Research Model}

The purpose of this study was to examine one preservice teacher's interpretation of student mathematical thinking using pattern recognition and linear function tasks. The research model is based on the qualitative research model since this type of research model "inquires into, documents, and interprets the meaning-making process" (Patton, 2015, p. 39). This descriptive study was conducted using a semi-structured interview technique (Maxwell, 1996). This semi-structured interview model provided the researcher with the flexibility to ask improvised questions during the interview while still following a consistent protocol with the participant.

\section{Participant}

The study presented in this article is a part of a broader study. The broader study was the researcher's dissertation study and explored Specialized Content Knowledge, Knowledge of Content and Students, and Interpretation Strategies of preservice teachers using Mathematical Knowledge for Teaching (Ball, Thames, \& Phelps, 2008) and professional noticing (Jacobs et al., 2010).

Eight preservice teachers from the Mathematics and Science Education Department of a major land-grant university in the southeastern Unites States voluntarily agreed to participate in the broader study. They were middle school mathematics preservice teachers. Those preservice teachers were Middle Grades Education (MAT) students. They were not yet certified and had not taught. Those preservice teachers from the MAT program were graduate students who had an undergraduate degree in some fields other than education. They were trying to get certified. Patton's (2015) convenience 
sampling was used and four of the eight preservice teachers were selected to participate in the broader study based on their schedule availability. Three of the participants were female and one was male. In this article, Amy's, interpretation strategies, one of the four preservice teachers, was explored. A pseudonym was used for the participant. Because Amy was able to explain what the numbers referred to in the students' work and how they might have come up with their solutions procedurally and conceptually, she was selected as the subject for this article. Also, Amy was able to articulate most of the solution strategies that were presented in the tasks students worked on when she solved the problems herself. She was the oldest participant, had the strongest content knowledge among the participants, and had taken more mathematics courses than the other participants. When the researcher talked informally with Amy after the interview, she told the researcher that she had taken several extra mathematics courses when she had attended to a community college. Amy possessed a warm, professional demeanor and demonstrated strong personal mathematical skills.

\section{Pilot Study}

A pilot study was conducted with two graduate students from the Mathematics and Science Education Department of the same university in the Unites States to check if the participants understood the tasks, videos, and interview questions. As a result of the pilot study, the interview questions were refined to better anticipate how preservice teachers might respond to questions regarding tasks. After the pilot study, the researcher considered in detail how to better conduct and have better camera shots. For example, colored tape was decided to be used in the actual study so that the edges of the camera shots could be easily determined. Also, one of the participants from the pilot study was left-handed; therefore, the researcher factored each participant's dominant hand into the actual study's design so that the camera would record the participants' hand writing clearly. After the pilot study, the researcher determined how many times the preservice teachers should be allowed to stop the videos based on the pilot study's participants' responses and recommendations.

\section{Data Collection}

The preservice teacher was not observed in any classroom setting. The data collected consisted of Amy's responses during a face-to-face, semi-structured interview and written work she produced during the interview. A transcript of the interview was also analyzed to produce data for this study. The interview was designed to explore the preservice teacher's interpreting strategies of student mathematical thinking.

Various sources were consulted to collect useful videos for Amy to analyze. Considering their length, quality, and content, materials from the teaching and learning modules constructed by the National Council of Teachers of Mathematics (NCTM) were selected. The criteria for determining which tasks provided the richest data on student mathematical reasoning were based on the effective teaching practices demonstrated in the videos. NCTM provided an overview of the videos and how they aligned with the teaching practices contained in Principles to Actions. Videos and tasks can be accessed at https://www.nctm.org/PtAToolkit/. The website has PowerPoint presentations, the video performances, lesson plans for each task, and transcripts of each recorded task while it was being performed. The Hexagon and the Two Storage Tanks tasks' materials can be accessed with NCTM membership, whereas the Counting Cubes task's materials can be accessed without such membership.

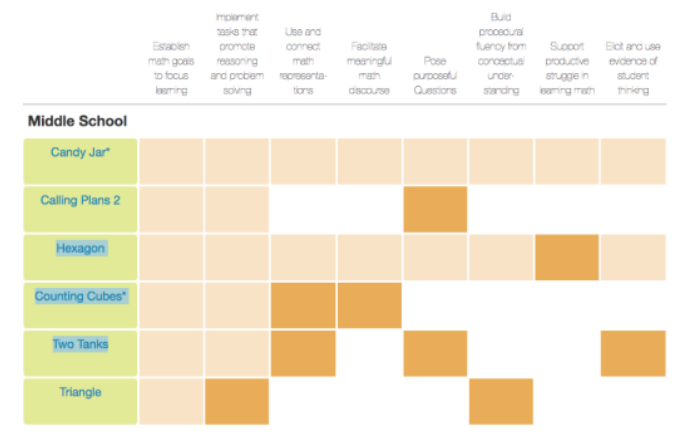

Figure 1: The screenshot of the middle school NCTM tasks with their related effective teaching practices on the top of the table 


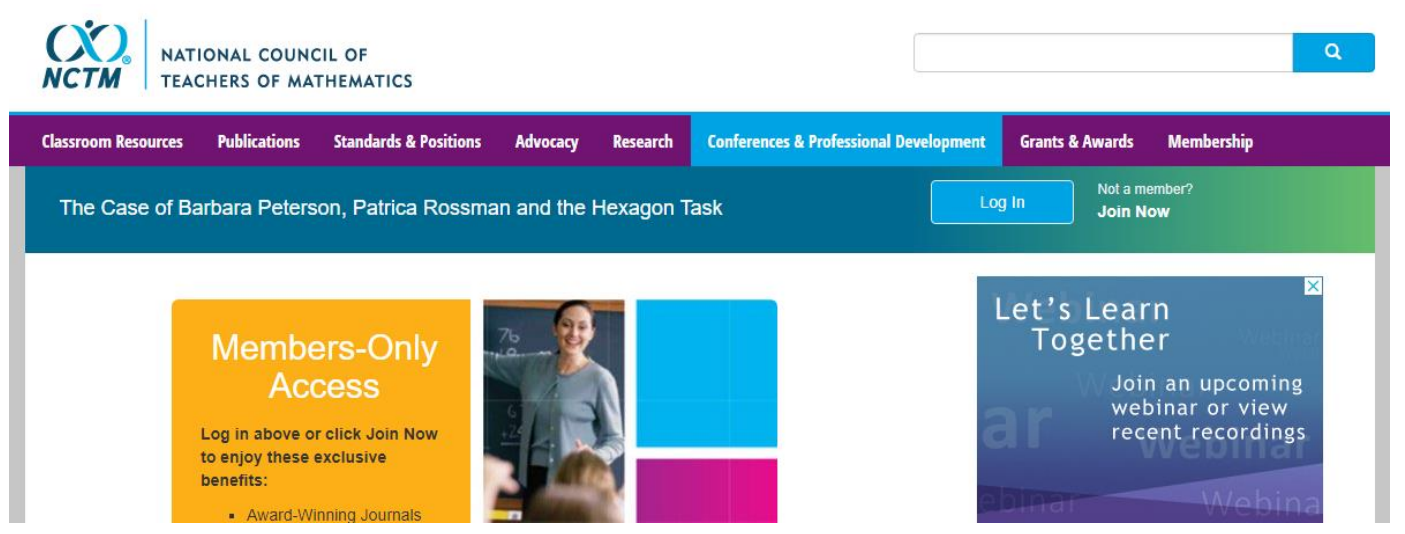

Figure 2: The screenshot of the NCTM website for accessing their materials

Student mathematical reasoning was the main focus of this study; therefore, the Hexagon, Counting Cubes, and Two Storage Tanks tasks were included, whereas the Calling Plans and Triangle tasks were excluded. The effective teaching practice demonstrated in the Hexagon task video was intended to support the productive struggle in learning mathematics. The effective teaching practices in the Counting Cubes task video were focused on using and connecting mathematical representations and facilitating meaningful mathematical discourse. The effective teaching practices in the Two Storage Tanks task video were concerned with using and connecting mathematical representations, posing purposeful questions, as well as eliciting and using evidence of student thinking. The commonality among these three tasks was their focus on student mathematical reasoning. The effective practices of the two tasks that were not selected (Calling Plans and Triangle) were, respectively, posing purposeful questions and building procedural fluency from conceptual understanding. These two tasks had less focus on students' reasoning and were focused more on teaching strategies and students' procedural understanding.

\section{In the Hexagon task video,}

Students tried to find the patterns of the perimeters of trains consisting of hexagonal wagons depicted with visual models. The visuals of the first four trains were given to students. The perimeter of the first train was 6 and consisted of one hexagonal wagon. The perimeter of the second train was 10 and consisted of two hexagonal wagons sharing one common side. The perimeter of the third train was 14 , consisting of three hexagonal wagons with adjacent hexagons sharing one common side. The perimeter of the fourth train was 18 , and it consisted of two hexagonal wagons with adjacent hexagons sharing one common side. The visual representation of the Hexagon task which can be accessed at https://www.nctm.org/Conferences-and-Professional-Development/Principles-to-Actions-Toolkit/TheCase-of-Patrica-Rossman-and-the-Hexagon-Task/ was as follows:

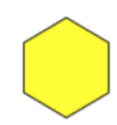

Train 1

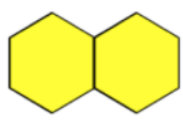

Train 2

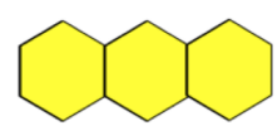

Train 3

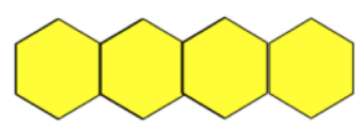

Train 4

Figure 3: Visual representation of the Hexagon task

The video started with one student from a group of students counting the perimeter of the trains as 26 , $30,34,38$, and 42 by emphasizing the pattern in the numbers. Then, the teacher in the video asked the students to find the perimeter of the $10^{\text {th }}$ train by using the patterns in the first four trains. Another student stated that the perimeter of the first train was six, and they could add four each time to the perimeter of the first train until they had 10 trains. The teacher then posed some questions to the students designed to promote their reasoning skills and critical thinking. The teacher in the video asked her students to show her the increase of four in the picture. One student responded that each hexagon in the middle of the train added four sides to the perimeter. Next, the teacher asked her students how much the hexagons at the beginning and at the end added to the perimeter of the train. They responded that each edge added five sides to the perimeter. After students recognized that the hexagons at the beginning and the end added five sides, whereas the hexagons in the middle added four sides to the perimeter of the trains, the 
teacher in the video asked her students to visualize in their minds how the $10^{\text {th }}$ train would looked like. She asked her students to explain their reasoning on the board. Students came up with the idea that the two hexagons on the edges added five sides, whereas the remaining eight hexagons in the middle added four sides to the perimeter of the hexagon.

2. In the Counting Cubes task video,

Students tried to find the patterns of the number of cubes in each building that consisted of five extensions. The first building consisted of one cube, the second building of six cubes, and the third building of 11 cubes. The visual representation of the Counting Cubes task which can be accessed at https://www.nctm.org/Conferences-and-Professional-Development/Principles-to-Actions-Toolkit/TheCase-of-Peter-Dubno-and-the-Counting-Cubes-Task/ was as follows:

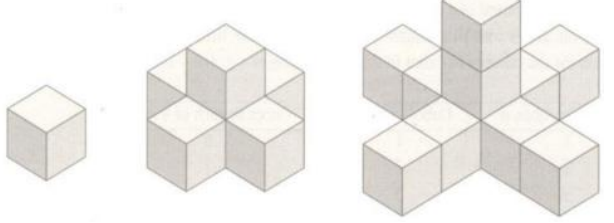

Figure 4: Visual representation of the Counting Cubes task

Students were asked to find the number of cubes for the $\mathrm{n}^{\text {th }}$ building by using the pattern in the first three buildings. They were also asked to find the number of cubes in the fifth building as well as to check their answers by constructing the fifth building. Two groups of students found different formulas for their patterns depending on how they defined the variable. One group consisting of two boys, Arden and Yoshio, found the pattern of the total number of cubes by using the formula $5 n+1$ where $n$ referred to the number of cubes in each extension. Arden first explained their formula $5 n+1$ and the meaning of $n$ in their formula. Then, Yoshio explained the volume of the $5^{\text {th }}$ building as $5 \times 4=20$ and $20+1=$ 21 where four referred to the number of cubes in each extension of the fifth building. They used volume referring to the number of cubes when they explained their solution. On the other hand, the other group, consisting of two girls, Cassie and Deirdre, found the pattern of the total number of cubes by developing the formula $5 n-4$ where $n$ referred to the building number. Cassie claimed that Arden and Yoshio's formula did not work for the first building. Arden defended that their formula worked for the first cube as well by using $5 \times 0=0$ and $0+1=1$ cube. The teacher in the video posed questions about why two groups of students found different patterns and what the similarities and differences were between the reasoning of these two groups of students. Another student from the video explained that what the variable $n$ referred to was different in two groups' formulas. Next, the teacher in the video asked Yoshio to explain the differences and similarities between their formula and the two girls' formula. In the end of the video, Arden explained that both their formula and the girls' formula could be used to find the number of cubes for each building.

\section{In the Two Storage Tanks task video,}

Students tried to find the amount of water in two storage tanks, one losing water while the other gained water simultaneously, but at different rates denoted by a graph. In the graph, one tank started with 900 gallons of water and lost 50 gallons of water in one hour. The other tank started with 300 gallons of water and gained 25 gallons of water in the same one hour. he visual representation of the Counting Cubes task which can be accessed at https://www.nctm.org/Conferences-and-ProfessionalDevelopment/Principles-to-Actions-Toolkit/The-Case-of-Elizabeth-Brovey-and-the-Two-StorageTanks-Task/ was as follows: 


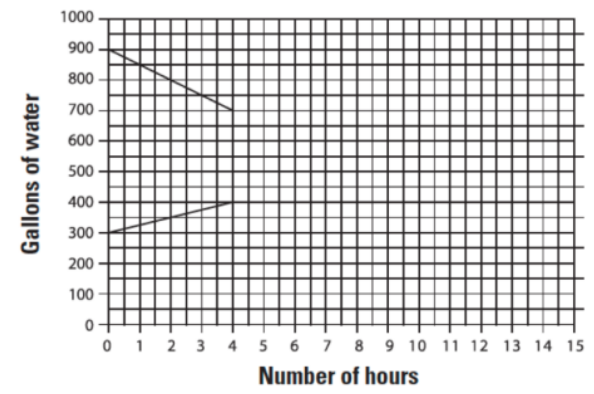

Figure 5: Visual representation of the Two Storage Tanks task

The teacher in the video posed questions to four students consisting of two boys and two girls in a group to help them develop equations to solve for the amount of water in each tank. In the beginning, the teacher asked one student, Marshall, what 900 referred to in the graph. Marshall explained that 900 was the head start referring that it was the starting amount of water for the tank which was losing water. The teacher asked another student in the group, Nicole, what 50 referred to in the graph. Nicole explained that 50 was the amount of water lost "every time". Then, the teacher asked what the time referred to, and the other female student in the group explained that time referred to "every hour." Next, the teacher asked another student, Leon, whether there was another equation that Leon wanted to explain in the graph. Leon explained the equation for the tank which was gaining 25 gallons of water in one hour. He explained that the tank was gaining 50 gallons of water. However, the tank in the graph was in fact gaining 25 gallons of water in one hour. The teacher asked Leon the amount of water after one hour to challenge him. After the teachers' prompts, the students in the group recognized that the tank was gaining 25 gallons of water, not 50 gallons of water in every hour. In the end of the video, the teacher asked the students to revise their equations based on the graph.

As part of the broader study, firstly the preservice teacher was asked to solve each of the three tasks as many ways as possible so that she would be better positioned to interpret student reasoning. After solving the tasks, the preservice teachers watched the videos about each task. The video for each of the three tasks was approximately five minutes long. In each video, middle school students solved a math task either as a small group or as a whole class. At the beginning of the interview, the researcher told Amy that she would watch each video twice.

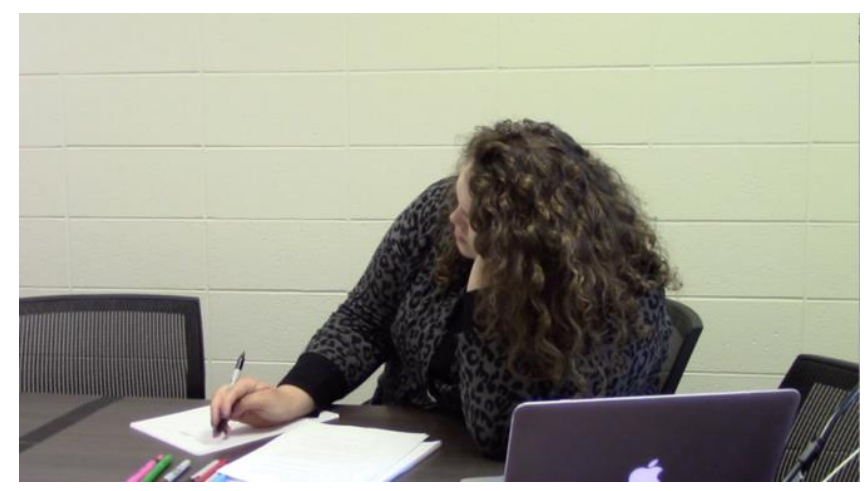

Figure 6: A screenshot of the interview when Amy was watching the NCTM videos.

The first time, she watched the video without stopping the video or making comments on it. However, she could take notes if she wished. Her first time watching the video, she was asked what she noticed about student mathematical reasoning. She was asked to pay attention to student mathematical reasoning in the video, but she was not prompted to pay special attention to any of the student mathematical reasoning. The researcher considered how much to ask the preservice teacher about the video so as not to affect the preservice teacher's interpretations of what she noticed. Possible probes for the first watching of the video were as follows:

a) What did you notice about students' mathematical reasoning? What caught your attention?

b) Did you notice any mistakes or misconceptions? 
c) Did you notice any similarities between students' mathematical reasoning in the video?

d) Did you notice any differences between students' mathematical reasoning in the video?

After watching the video, she explained what she noticed about student mathematical reasoning, whether she noticed any students' mistakes or misconceptions, and if she identified any similarities or differences between student mathematical reasoning. After recording her responses, she watched the video a second time. This time, she watched the video with the remote, and she was told that she could stop the video whenever she wanted, as many times as she wanted. She was told to note more specific aspects of students' mathematical reasoning and was given a table consisting of four columns, each labeled respectively: important mathematical ideas, students' mistakes and misconceptions, similarities between student mathematical reasoning, and differences between student mathematical reasoning. Possible probes for the second watching of the video were as follows:

a) What are the important aspects of students' mathematical reasoning?

b) What are students' mistakes and misconceptions?

c) What are similarities between students' mathematical reasoning in the video?

d) What are the differences between students' mathematical reasoning in the video?

Similar to the first watching of the video, the researcher maintained the interview questions as broad as possible. She aimed not to lead Amy toward any specific student or any specific aspect of the video so as not to impact her interpretations. She recorded her responses on a table when she watched the videos a second time.

Regarding the number of times participants were shown the video for each task, Mason (2002) preferred to show a video only once because things happen only once in real life. He thought that watching a video once would approximate the actual teaching environment. However, in this study, video studies are considered to be a useful tool for the preservice teacher to learn the practice of teaching and for the researcher to explore her knowledge. The reasoning of the researcher of this study was consistent with Sharpe, Hu, Crawford, Gopinathan, Khine, \& Moo's (2003) claim that they “had naively assumed that it would be easy for everyone to make sense of a 3-min video clip during the conference. In fact, we found that we had to run the clips backwards and forwards on a number of occasions to make sense of them" (p. 539). Thus, the researcher of this study chose to show each video twice. When she watched a video for the second time, she had an opportunity to add more information and to confirm or change her thought from watching the video the first time.

\section{Data Analysis}

Coding for the interpretation phase of professional noticing was based on the participant's responses regarding 1) important mathematical ideas, 2) mistakes and misconceptions, 3) similarities between students' reasoning, and 4) differences between students' reasoning in the videos. A three-point rubric was used for measuring the preservice teacher's interpretation strategies. Jacobs et al.'s (2010) description of robust evidence, limited evidence, and lack of evidence of teachers' interpretations of children's understanding impacted this research. The extent of the preservice teacher's interpretation strategies was related to the details she provided and evidence she supplied. The following factors were considered when reviewing the participant's explanations: 1) the depth of details she provided regarding specific children's strategies, 2) whether she focused on specific children versus a group of children, 3) the extent of specificity she provided regarding mathematical concepts children need to know, and 4) whether she made overgeneralized conclusions. The following response of Amy, for example, was regarded as robust evidence of her interpretations:

One kid was looking from at one hour time point, so looking at the time frame of zero to one hour and not paying attention to what the y axis represents. So, it is half way between two grid lines that must represent like 50. The next grid line was 400, and the other one was 900. Whereas another girl, which was a lot smarter, you want to find or like a smarter decision in this case wanted to look at the two-hour mark because it actually crosses a grid line exactly. So, that looking at the amount of water at different time points, another kid could just look straight at 400 because that is where it goes or at 4 hours because that's where it crosses the 400 line. 
In her interpretations above, Amy was able to specify which students reasoned in which way. Also, she provided specific numbers and concepts from the video. She compared different students' thinking and explained her reasoning. The following response of Amy, for example, was regarded as limited evidence of her interpretations:

The easiest way to see the addition of 4 to each subsequent perimeter is if you add the hexagon to the middle, so like from train 3 to train 4, you've got 3 hexagons, then you've got 4 hexagons. Well, that fourth hexagon is being added somewhere in the middle. So, that's why we are adding 4.

In her interpretations above, Amy was able to provide some numbers from the task However, she did not relate her interpretations with a specific student's reasoning or a group of students' reasoning in the video. The following response of Amy, for example, was regarded as lack of evidence of her interpretations:

The third similarity was just they all made an equation. They all realized that they needed to make an equation, but they are working together, and so they all answer different questions that one kid was speaking as a group. So, they pretty much agreed on everything, and everything was kind of similar in their reasoning from what I can see.

In her interpretations above, Amy made overgeneralized conclusions and did not elaborated on her reasoning. Her language was vague and did not specify any student or students in her interpretation.

\section{Findings}

The following three figures were Amy's written work. Amy's written work on the table when she watched the Hexagon task a second time was as follows:

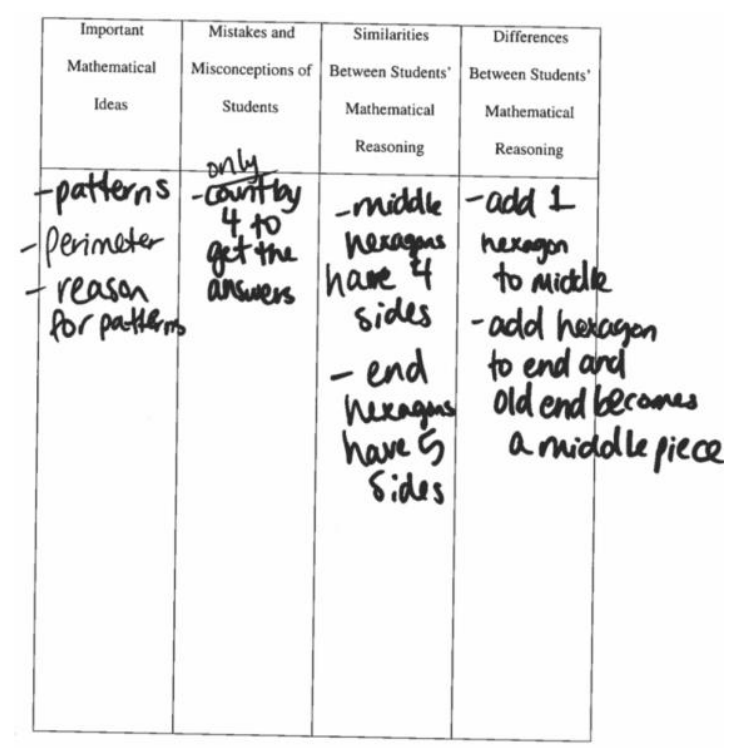

Figure 7: Amy's written work in the Hexagon task

Amy's written work on the table when she watched the Counting Cubes task a second time was as follows: 


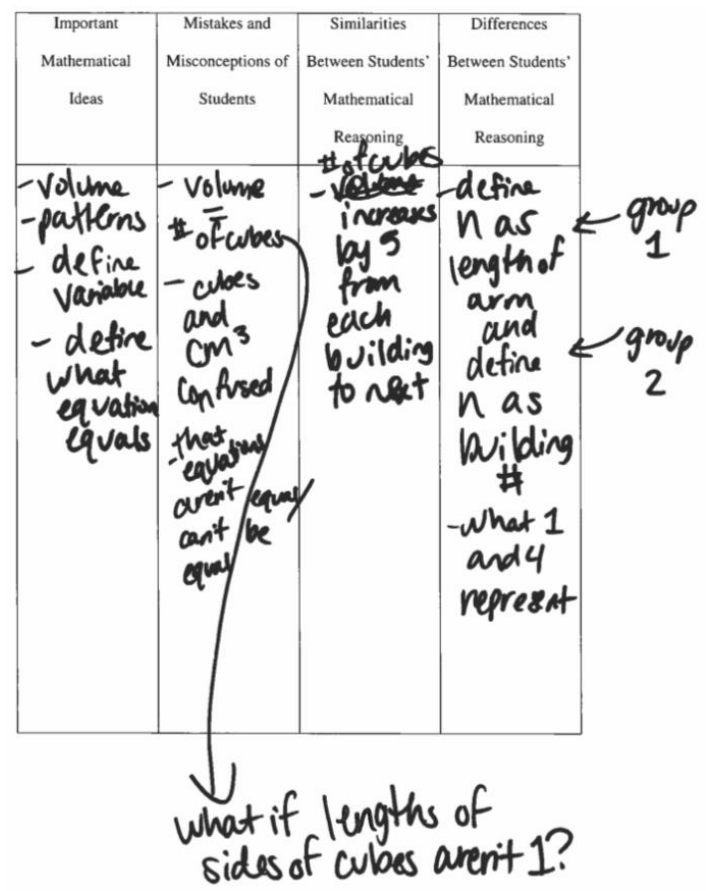

Figure 8: Amy's written work in the Counting Cubes task

Amy's written work on the table when she watched the Two Storage Tanks task a second time was as follows:

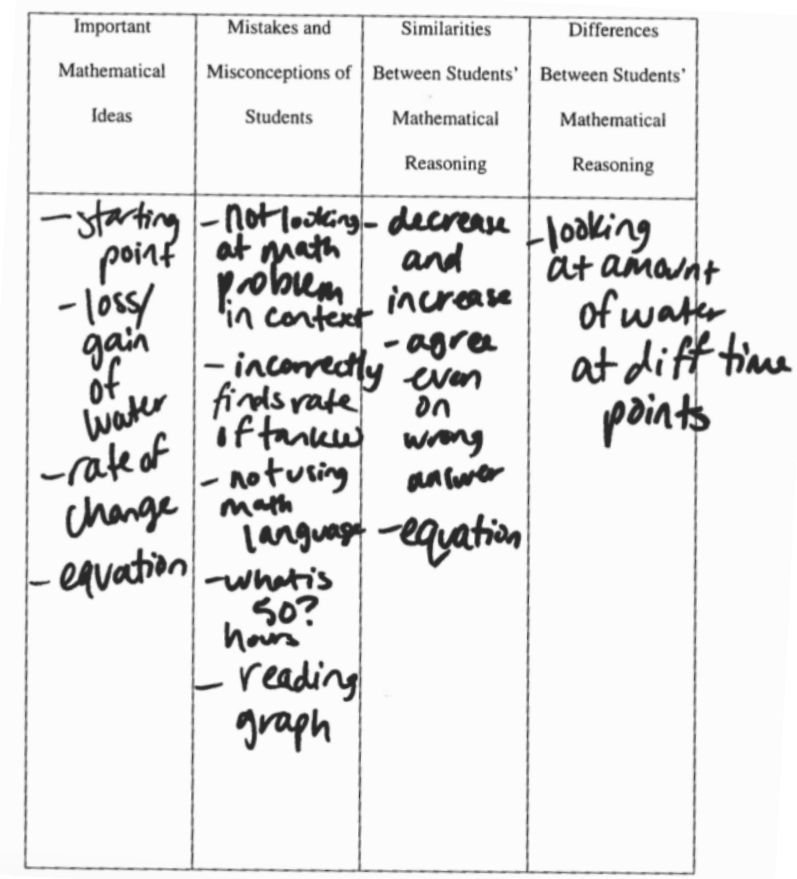

Figure 9: Amy's written work in the Two Storage Tanks task

In the following section, this study evaluated Amy's performance on tasks requiring her to identify the following themes in student mathematical reasoning from the videos: 1) important mathematical ideas, 2) mistakes and misconceptions, 3) similarities between students' reasoning, and 4) differences in students' reasoning. 


\section{First Theme: Important Mathematical Ideas}

In the following section, the preservice teacher's responses on the first theme, important mathematical ideas, was explained on the Hexagon, Two Storage, and Counting Cubes tasks.

\section{Hexagon task}

The first time she watched the video, Amy identified patterns as an important mathematical idea, explaining, “... they did figure out the pattern. They first figured it out with the perimeter, just adding 4 each time but then they were also able to pick out why there was four, where was actually 4 coming from the diagram." The second time Amy watched the video, she indicated that 1) patterns, 2) the perimeter, and 3) reasoning for patterns are important mathematical ideas. Amy stated that "if you can recognize the patterns, then you can get a deeper understanding of the math," explaining, "the reason why I think patterns are like important is, I mean anybody can sit there and count, but you don't want to count. We want them to see the bigger picture in that as there are patterns to it." In terms of how students use patterns, Amy expressed that students "were able to pick out why we are adding 4"

Amy described the perimeter as being one of the important mathematical ideas students needed to understand: "them (referring to the students) being able to recognize that just because the hexagon has six sides, we are not counting six sides in the perimeter. You know you need to understand what the perimeter is." Amy explained reasoning for patterns as an important mathematical idea as follows:

The easiest way to see the addition of 4 to each subsequent perimeter is if you add the hexagon to the middle, so like from train 3 to train 4, you've got 3 hexagons, then you've got 4 hexagons. Well, that fourth hexagon is being added somewhere in the middle. So, that's why we are adding 4. But then, another student was saying that you are going to add that fourth hexagon to the end but then the old one becomes the middle piece. So, like that end piece that had five now has four and the new end piece has 5. So, that was kind of the differences of where you are going to put that extra hexagon.

During the first viewing, Amy noticed the students understood that there was a pattern between the perimeters of the trains. However, it was only after she paused that she noticed the relationship between the pattern and the perimeter concepts was important.

\section{Counting Cubes task}

When Amy first watched the video, she stated that the definition of the variables was an important mathematical idea: "The second group, the two girls, they pretty much have the same idea with different equations. So, they've got to a discussion about how defining the variable is really important." The second time watching the video, Amy considered 1) volume, 2) patterns, 3) defining variables, and 4) defining what each of the expressions referred to (i.e., explaining what $5 n+1$ and $5 n-4$ refer to) as important mathematical ideas. In terms of volume as an important mathematical aspect, Amy explained that, "The volume is important because otherwise, they can't even answer the question you are looking for." Regarding patterns as another important mathematical aspect, she said that, "Everything in math is about patterns and recognizing what is going on. That is important to be able to set the equations." To consider defining variables as an important mathematical aspect, she asserted that,

Defining variable is important because, you know, what does $n$ represent? Because the second group, they were trying to say that this $5 n+1$ equation is not always going to work because they were considering $n$ to be the number of the building. If we said that $n$ was the number of, like, what the building number it was in this first equation, it would not always be right. In fact, I do not think it ever be right because they are going off the leg length, the length of one arm as what $n$ represents in this equation and here, it is the building number. So again, we have to know what the variable is or else we are going to get the wrong answer.

Regarding defining what each of the expressions $5 n+1$ and $5 n-4$ referred to as an important mathematical aspect, Amy noted that,

This is just the volume and the number of cubes. That is a huge difference and it becomes a huge difference if, like our volume, I just made a note 'what if the lengths of the sides of the cubes are 
not one?' Well then, $5 n+1$ is not going to equal to the volume. So, we have to make sure that we are clear on what we are finding the answer to. Like, is this the half of the volume, for example?

Amy quickly noticed that the students comprehended they needed to solve for a variable. However, it was only after she slowed down that she noticed the students were relying on their understanding of the patterns to develop variable equations.

\section{Two Storage Tanks task} explaining,

Her first time watching the video, Amy regarded the time as an important mathematical idea,

The first girl said that you lose 50 every time. Well, what is every time? And that is really important in an equation like this. Are you losing 50 gallons a day because that is going to make a difference. Are you losing 50 gallons every 3 hours, every hour?

The second time she watched the video, in terms of the important mathematical ideas, Amy asserted that 1) starting point, 2) loss or gain of water, 3) rate of change, and 4) equation were important ideas. Amy explained that starting point was an important mathematical idea:

So, an important aspect was that there was a starting point for the number of gallons in each of the tanks. That is really important to make the equation. It is important to even solving the whole problem, but they recognized they caught different things, I guess. I hear one student called [it] "the head start," but they recognized that there is a starting point on your y intercept.

Amy explained why understanding the loss or gain of water was an important mathematical idea:

It is important to know which one you are working with because a loss or gain is a big difference, and it contributes being able to solve the problem. But they realize that one tank was losing water, so you want to subtract water from it; the other one was gaining water, so you want to add water to it.

To explain why the rate of change was the third important mathematical idea, Amy noted that,

Understanding slope is really important even though they did not really talk about that much, but they can tell from their mistake that rate of change makes a big difference." An equation was the fourth important mathematical idea, which Amy explained by saying: "So, they were not just like trying to use the table. They could use an equation to solve this.

Amy noticed that one female student in the video talked about the amount of change over time. However, it was only after she slowed down that she noticed there were more important mathematical concepts such as starting point, loss or gain of water, rate of change, and the equation, which were discussed in the video. During the second viewing, Amy provided more concepts. She not only emphasized what students mentioned in the video but also what they did not mention but important in the task.

\section{Second Theme: Students' Mistakes and Misconceptions}

In the following section, the preservice teacher's responses on the second theme, students' mistakes and misconceptions, was explained on the Hexagon, Two Storage, and Counting Cubes tasks.

\section{Hexagon task}

Her first time watching the video, Amy did not report any mistakes or misconceptions. The second time she watched the video, Amy regarded only counting by 4 to get the answer as a student mistake or misconception. She asserted that,

[The] first train has a perimeter of 6. That does not really fit in our pattern while we go from zero to 4 . Why did we start out with 6 ? why are we counting by 4? And so, I also think just the misconception is that you would only count by 4, may be 'only count by 4' because that is not the only way you could do it. 


\section{Counting Cubes task}

Her first time watching the video, Amy described students' mistakes and misconceptions as follows:

The misconception is just that there can't be more than one equation to define this pattern. The mistake is just, I mean the technicality, the $5 n+1$ is equal to the volume, which like I said is not always going to be true. So, that is to me, a mistake even though they've pretty much got the idea. But then, I do like how they kind of worked it out and realized that these equations were not the same depending on what your $n$ is.

The second time Amy watched the video, she noticed the following mistakes and misconceptions: 1) volume being equal to the number of cubes, 2) cubes and $\mathrm{cm}^{3}$ were confused, 3) equations are not equal/cannot be equal. With respect to volume being equal to the number of cubes, Amy stated that, "I just made a note 'what if the lengths of the sides of the cubes are not one?' Well then, $5 n+1$ is not going to equal to the volume." Pertaining to the second mistake and misconception, cubes and $\mathrm{cm}^{3}$ being confused, Amy gave the following example:

You can tell that the kid kind of stumbles whenever he is giving the explanation that $5 n+1 \ldots$ or he said that from building 1 to building 2, the volume increases by 5 cubic centimeters. Well, you know, are you increasing by 5 cubes or are you increasing by 5 cubic centimeters, which 5 cubic centimeters would be true? If the lengths of the sides of the cubes are one, then you would be increasing by 5 cubic centimeters and that would be okay if we are going to make a rule that our cubes are just one by one by one or are you just increasing by 5 cubes, in general.

In terms of the third misconception, that equations are not equal/cannot be equal, Amy explained the following:

The other misconception of the students was that the equations the two groups gave could not be equal and that they were not equal. And so, I think that it comes down to defining your variables and that these two equations could be worked out where they are equal to each other. It is the same equation, just written differently, because we have defined our variables in different ways.

Amy quickly noticed the students had misapprehended what to consider as the equation of the pattern. However, it was only after she watched the video a second time that she noticed more details about students' misunderstanding of the need to have only one equation for the pattern of the number of cubes.

\section{Two Storage Tanks task}

Her first time watching the video, Amy explained that the students erroneously thought that tank W was gaining 50 gallons every hour instead of 25 gallons every hour, which "just came from reading the graph wrong." The second time she watched the video, Amy noticed the following student mistakes and misconceptions: 1) not looking at the math problem in context, 2) incorrectly finding the rate of tank W, 3) not using math language, 4) what is 50 hours? and 5) reading the graph. With respect to not looking at the math problem in context, Amy explained that, "[Students] are just trying to solve two equations; they were not really thinking about what it means... So, not looking at the math problem in context is a problem." Regarding the second mistake or misconception, incorrectly finding the rate of tank W, Amy stated that, "The student incorrectly found the rate of tank W. And so, that was gaining 50 gallons every hour when it was actually only gaining 25 gallons every hour." Pertaining to the third mistake or misconception, not using math language, Amy stated the following:

Not using mathematical language is important to me. So, you know, I am subtracting by 50.900 is the head start. Like 900 is your y intercept; 900 is your initial number of gallons. So, I just think that using correct mathematical language will make it a little bit more concise and easier to talk about.

In addition, Amy stated that one of the students did not know what 50 refers to, explaining,

The teacher asked what is 50 and the kid said hours at first. So, this just goes back to looking at the problem in context. Well, that 50 is the number of gallons. Look at what your axes of the 
graph represent. Well, the y axis represents the gallons of water. So, you are losing 50 gallons of water over an amount of time, and it just happens to be an hour. And so, probably made that mistake, just guessing. I mean they are like, okay, 50 is either the number of hours or gallons of water and just took a wild guess.

Also, she explained the fifth mistake as "The other mistake is just like reading the graph in general. So, you know, and that comes from incorrectly identifying what 50 is and incorrectly finding the rate of change of tank W." Some of the mistakes that Amy provided were related. For instance, 50 gallons per hour vs. 25 gallons per hour was related to reading the graph wrong because the mistake was related to not understanding the scale on an axis.

Amy noticed students' inability to read the graph correctly. However, it was only after she slowed down that she noticed more details about where students made mistakes and where the misconceptions occurred in the video.

\section{Third Theme: Similarities in Students' Reasoning}

In the following section, the preservice teacher's responses on the third theme, similarities in students' reasoning, was explained on the Hexagon, Two Storage, and Counting Cubes tasks.

\section{Hexagon task and Counting Cubes task}

In the Hexagon task video, during both the first and second viewing, Amy noted that students understood that the first and last hexagons contribute 5 edges to the perimeter while the middle hexagons each contribute 4 units to the perimeter. Amy's observations did not change from her first to second viewing of the video on the similarities in students' reasoning.

In the Counting Cubes task video, her first time watching the video, Amy stated that both groups "recognized the pattern of how many cubes they are going to have." The second time watching the video, Amy noted that the students realized that the number of cubes increased by 5 from each building to the next. Amy noticed more details about the patterns of the cubes, such as the number of increases by 5 cubes, regarding the similarities in students' reasoning.

\section{Two Storage Tanks task}

Her first time she watched the video, Amy did not notice any similarities in student mathematical reasoning. The second time Amy watched the video, she noticed the following similarities in student mathematical reasoning: 1) decreasing and increasing, 2) agreeing even on a wrong answer, and 3) recognizing that they needed to come up with an equation. Amy noted that two students "both recognized the tanks are decreasing and increasing in the amount of water." She recognized that two students "agreed that the second tank was gaining 50 gallons every hour," even though this answer was not correct. Amy expressed the third similarity in students' thinking, equation, as follows:

The third similarity was just they all made an equation. They all realized that they needed to make an equation, but they are working together, and so they all answer different questions that may be one kid was speaking as their group. So, they pretty much agreed on everything, and everything was kind of similar in their reasoning from what I can see.

She meant that students came up with an equation as a group, and one student each time was explaining different parts of the equation on behalf of the group, and the rest of the group members were agreeing with each of the students who spoke on behalf of the group. The second and third similarities that she reported were related to each other. Amy provided more details about the similarities in students' reasoning about how many students reasoned similarly. After she watched the video a second time, she noticed the number of students, two, who reasoned similarly.

\section{Fourth Theme: Differences in Students' Reasoning}

In the following section, the preservice teacher's responses on the fourth theme, differences in students' reasoning, was explained on the Hexagon, Two Storage, and Counting Cubes tasks. 


\section{Hexagon task}

Her first time watching the video, Amy did not notice any differences in student mathematical reasoning. The second time she watched the video, Amy considered 1) adding 1 hexagon to the middle and 2) deciding to add a hexagon to the end of the sequence so that the old end of the sequence becomes a middle section would indicate differences in student mathematical reasoning. In terms of adding one hexagon to the middle as the difference between student mathematical reasoning, Amy stated that,

The easiest way to see the addition of 4 to each subsequent perimeter is if you add the hexagon to the middle, so like from train 3 to train 4, you've got 3 hexagons, then you've got 4 hexagons. Well, that fourth hexagon is being added somewhere in the middle. So, that's why we are adding 4.

Amy argues that some students' abilities to recognize that the hexagon sequence could be altered as part of their process for solving the problem indicated different proficiencies in students' reasoning abilities. She further explained that,

Another student was saying that you are going to add that fourth hexagon to the end but then the old one becomes the middle piece. So, like that end piece that had five now has four and the new end piece has 5. So, that was kind of the differences of where you are going to put that extra hexagon.

The first and the second differences that Amy provided were related to each other because in both scenarios, students recognized that each time a new hexagon was added, they also added four sides to the perimeter. However, in the first method, students considered adding the new hexagon in the middle of the previous train, whereas in the second method, students considered adding the new hexagon in the end of the previous train, and the older hexagon at the end of the previous train became the middle hexagon.

\section{Counting Cubes task}

Her first time watching the video, Amy reported the definition of the variables as the differences between student mathematical reasoning: "Differences would be what they have defined to be the variable. Are we going to use the length of arms or legs, whatever you want to call them or are we going to use the building number?" The second time she watched the video, Amy regarded the differences between student mathematical reasoning as follows: 1) group 1 defining $n$ as length of arm and group 2 defining $n$ as building number and 2) what 1 and 4 represent in the expressions $5 n+1$ and $5 n-4$, respectively. She explained that,

Group 1 was looking at 1 as being that beginning volume or beginning number of cubes. You are starting out with one cube, like that's your beginning, whereas the second group was kind of thinking that, let's do 5 times the building number and then we need to subtract 4.

Amy was more specific in explaining what she noticed as the differences in students' reasoning in the Counting Cubes task. She labeled the groups as group 1 and group 2 when she explained the differences. She also noticed more details about the meaning of the variables after she watched the video a second time. She noticed that in their representations, students referred to the variable as $n$. She elaborated the group's reasoning in more detail with specific numbers such as explanations of 1 in the expression $5 n+$ 1 and 4 in the expression $5 n-4$.

\section{Two Storage Tanks task}

The first time Amy watched the video, she did not notice any differences in student mathematical reasoning. The second time she watched the video, Amy noticed that looking at the amount of water at different time points indicated a difference in student mathematical reasoning. She explained that,

One kid was looking from at one hour time point, so looking at the time frame of zero to one hour and not paying attention to what the y axis represents. So, it is half way between two grid lines that must represent like 50. The next grid line was 400, and the other one was 900. Whereas another girl, which was a lot smarter, you want to find or like a smarter decision in this case 
wanted to look at the two-hour mark because it actually crosses a grid line exactly. So, that looking at the amount of water at different time points, another kid could just look straight at 400 because that is where it goes or at 4 hours because that's where it crosses the 400 line.

During her second viewing of the video, Amy noticed that what students looked at regarding the range of time differed: either one, two, or four hours. She noticed the differences among three students' reasoning when she paused the video during the second viewing.

\section{Discussion}

Amy focused on groups of students rather than a specific student, and she provided sufficient details regarding students' strategies. The following demonstrates one of her detailed explanations:

The easiest way to see the addition of 4 to each subsequent perimeter is if you add the hexagon to the middle. So, like from train 3 to train 4, you've got 3 hexagons; then you've got 4 hexagons. Well, that fourth hexagon is being added somewhere in the middle. So, that's why we are adding 4 [to the perimeter]. But then, another student was saying that you are going to add that fourth hexagon to the end, but then the old one becomes the middle piece. So, like that end piece that had five now has four and the new end piece has 5. So, that was kind of the differences of where you are going to put that extra hexagon.

It is possible that what she paid attention to might impact her interpreting skills. Studies also argues that attending and interpreting skills are related to each other (Jacobs et al., 2010; Fisher, Thomas, Jong, Schack, \& Dueber, 2019). With regard to specific concepts students used, Amy identified important concepts, such as perimeter, pattern, rate of change, slope, intercept, equation, variable, and volume; however, she did not define those concepts. Additionally, the following excerpt demonstrates Amy's tendency to make overgeneralized conclusions:

The third similarity was just they all made an equation. They all realized that they needed to make an equation, but they are working together, and so they all answer different questions that one kid was speaking as a group. So, they pretty much agreed on everything, and everything was kind of similar in their reasoning from what I can see.

She considered that all of the students shared similar reasoning approaches; however, she did not have enough evidence to properly conclude that all of the students in the group were thinking in similar ways. This overgeneralization of regarding students as a group was a similar tendency in Fernández, Coles, and Brown's (2013) study. It is possible that students preferred to be quiet and did not express what they understood or did not understand. Because she did not have access to each of the students' reasoning and only one student was talking, the assumption that the students were using the same reasoning approaches because some of them were quite is a possible fallacy. Quite students do not necessarily indicate that they did not use different reasoning strategies. It was possible that some of the students did not follow their peers' examples and simply preferred to remain quiet and not share their processes. Amy mostly provided valid judgements and supported her reasoning with evidence. The strength of her evidence varied depending on what aspects of student mathematical reasoning, either a specific student's reasoning or mathematical aspect of students' reasoning, she focused on. When Amy explained students' reasoning, her explanations did not necessarily reflect the students' reasoning, but rather her own reasoning of the problem. When Amy explained how the reasonings of the two girls and the two boys in the video differed, her explanation of the two girls' understanding of what -4 means in $5 n-4$ is the same as her own explanation when she solved the problem herself.

The second group [two girls], you have this height of two and the lengths of the legs are just one. And so, they are subtracting 4 because the height and the lengths of the legs are not the same. Whenever they multiply by 5, they are making the height and the length of the legs the same. And then, they have to subtract 4 to get rid of the extra one of the legs that are not there.

The two girls explained how they came up with the expression $5 n-4$ as follows; however, they did not explain what -4 referred to in their expression:

Originally, we got what Arden [one of the students from the other group of two boys] got, but we tried it out, and it [referring to the expression $5 n+1$ ] didn't always work with the first one 
[referring to plugging in 1 to find the number of cubes in the first building]. So, what happened is we came up with $5 n-4$, so it's 5 arms and then $n$ would be the building number. And then you subtract 4 and then you get the number of cubes in the building. So, we wrote up an example and $n=2$, so then $5 \times 2-4$ is $10-4$, we got 6 cubes in the building.

The two girls were assuming that the two boys' expression $5 n+1$ cannot be generalizable, and both girls had difficulties explaining what $n$ means in the two boys' expression $5 n+1$. Rather than these two girls, it was another student in the video who could explain why both the girls' and the boys' expressions actually worked:

Wait 1 second. I think what Arden is trying to...He defined $n$ as the length of one arm, so for the first building it would be 0, not 1. And you were trying to do the building number. So, that's what was different about it. That's why you're having this quarrel.

In addition, instead of the two girls, one of the two boys, Arden, was the one who explained how their expression $5 n+1$ differed from the two girls' expression $5 n-4$. He explained,

We did the middle square for each arm and then you subtracted 4 middle squares. But what we did is we just added the actual length of the arm excluding the middle square... It's really just the same thing. It just depends on how you think of it.

Although one student from the class was the one who could explain the meaning of $n$ in both the girls' and boys' groups, and Arden was the one who could explain the meaning of +1 in the expression $5 n+$ 1 and -4 in the expression $5 n-4$, Amy interpreted the scene as if the two girls could explain the meaning of -4 in the expression $5 n-4$. Since Amy could explain what -4 means in the expression when she solved the problem herself, she subconsciously assumed the girls knew the meaning of -4 in the expression $5 n-4$. However, the two girls, in fact, could not explain what -4 refers to, and Amy's interpretation of the two girls' explanation did not actually match up with these girls' actual responses in the videos. In other words, Amy's interpretation emphasized the meaning of -4 in the expression $5 n-4$ mathematically in isolation from how the two girls actually reasoned through the problem. In general, Amy scored a mix of $1 \mathrm{~s}$ and $2 \mathrm{~s}$ on the interpreting skills rubric.

\section{Conclusion and Recommendations}

\section{In terms of interpreting important mathematical ideas in students' work in the videos}

It is found that the preservice teacher provided the author of this study with specific important mathematical ideas and explained their meaning in depth. Similarly, Callejo and Zapatera (2017) investigated preservice teachers' noticing of students' thinking by using pattern generalization problems. They identified that five preservice teachers teaching competence levels varied from not identifying any characteristics of students' understanding of pattern generalization to identifying different characteristics of students' understanding in detail. Also, Magiera and Zambak (2021) investigated preservice K-8 teachers' professional noticing of students' justifications and generalizations of figural patterns by using written artifacts and video-records. They found that preservice teachers provided more details about mathematically significant aspects of students' thinking when they analyzed students' written work compared to the video-records. These findings show that preservice teachers have the potential to identify in detail various aspects of student mathematical thinking. More research is needed to explore different ways to help preservice teachers achieve their full potential with regard to identifying and providing explanations of student mathematical reasoning.

\section{In terms of interpreting students' mistakes and misconceptions}

The preservice teacher did not report any student mistakes and misconceptions in the Hexagon task when she watched the video for the first time. The lack of teacher commenting may be linked to the nature of the video-based assessment (Sharpe et al., 2003). There appears to be evidence suggesting that using videos in professional noticing studies does not prompt teachers to comment on mistakes the same way they might when interacting with children in a classroom setting. Also, showing students' written work can impact preservice teachers' interpreting skills differently since preservice teachers can see students' work for longer periods of time rather than momentarily. Therefore, these types of artifacts might have an impact on interpreting strategies (Kersting, 2008; Jakobsen et al., 2014; Kilic, 2018). 
These findings are not surprising; the literature indicates that defining (Stahnke et al., 2016) and measuring (Nickerson, Lamb, \& LaRochelle, 2017) teachers' professional noticing and using videobased assessments (Kaiser, Busse, Hoth, König, \& Blömeke, 2015) could have obstacles. Nickerson et al. (2017) focused particularly on measuring secondary mathematics teachers' professional noticing of student mathematical thinking. They emphasized three methodological challenges: choosing artifacts, deciding the respective sophistication of responses, and a lack of access to secondary level professionals' responses. Kaiser et al. (2015) elaborated more on the methodological challenges of constructing videobased assessments for teachers' competence. They reported the following methodological challenges in developing a video-based assessment instrument for teachers' competence: designing assessment instruments, developing test items, defining "correct" and "wrong," and ensuring sufficient psychometric quality. Researchers need to predict and consider these methodological obstacles before they conduct research on teachers' professional noticing.

When the preservice teacher interpreted students' mistakes or misconceptions, she explained the misconceptions mathematically rather than providing specific examples from the video. Jacobs et al. (2010) underlined the importance of specificity and the extent to which providing details on specific students' reasoning issues can indicate strong interpreting skills. However, her interpretations of the mistakes were potential mistakes that students might have made rather than specific mistakes that students did make in the video. She described the challenging parts of the tasks mathematically and provided some specific details regarding students' reasoning. In the Two Storage Tanks task, for example, Amy was more specific and more student-focused compared to her behavior in the other tasks. The preservice teacher reported that students' mistakes and misconceptions in the Hexagon task were because they did not understand the perimeter of the first two trains. The preservice teacher was able to identify students' mistakes and misconceptions and provide detailed reasoning regarding why she considered these issues students' mistakes or why she believed they indicated students' misconceptions of mathematical principles. Moreover, she reported that students did not understand the meaning of the variables in all three tasks. The preservice teacher's variance in meaningful commentary and feedback across tasks and with regards to content is reflected in research by Choppin (2011) and Ulusoy (2020), respectively. Choppin (2011) found that what teachers noticed gave some information about how those teachers adapted challenging tasks regarding the limitations and advantages of task features as well as how teachers organized student activity while accounting for those task features. Ulusoy (2020) found that when preservice teachers analyzed two mathematics teachers' instructions, preservice teachers improved their attending and interpreting skills regarding content-specific characteristics of instruction rather than general characteristics of instruction. More research is needed to help us understand how and why different tasks and contents might impact preservice teachers' professional noticing differently.

\section{In terms of interpreting the similarities between students' reasoning}

The preservice teacher's description of the similarities between students' reasoning was broad. She did not point out any students when she described the similarities; she only identified common student understandings rather than common student misunderstandings in the videos. Teachers' understanding of topics is reflective of their quality of their teaching (Ma, 1999). The literature has shown that interpreting students' misunderstandings and learning from those misunderstandings can provide chances for preservice teachers to check their own generalization knowledge as well as justification of patterns (Tanış11, Yavuzsoy Köse \& Camci, 2017) and how to challenge and control for those tendencies when teaching (Kilic \&Dogan, 2021).

\section{In terms of interpreting the differences between students' reasoning}

The first time the preservice teacher watched the Hexagon task video and the Two Storage Tanks task video, she did not notice any differences between students' reasoning. She explained the differences in students' reasoning in the Counting Cubes task and Two Storage Tanks task videos by providing evidence when she watched the videos the second time. However, she did not explain the differences between students' reasoning with evidence in the Hexagon task. So, depending on the task and how many times she watched the videos, either one or two times, the extent to which she provided evidence varied. These findings are aligned with Sharpe et al.'s (2003) argument that the number of times 
preservice teachers watch the video might have some impact on the depth of detail they provide in their interpretations.

In summary, it is revealed that the strength of the preservice teacher's interpretation strategies varied depending on the tasks. The richness of the student thinking and the abundance of mathematical conversations among the teacher and students in each video might have impacted the difference, even though there could be other possible features of the tasks which impacted the preservice teacher's interpretation strategies. The preservice teacher did not provide detailed explanations of students' reasonings when watching NCTM videos even though she solved all the tasks in multiple ways and explained the key concepts while solving the problems before watching the videos. The literature has also shown that preservice teachers might struggle to provide details about students' reasoning (Didis et al., 2016; Phelps-Gregory \& Spitzer, 2018).

\section{Acknowledgements}

This study is based on the dissertation study conducted by the researcher, Ebru ERSARI, at the University of Georgia. I would like to thank my advisor Dr. Denise Spangler and my committee members Dr. Anna Conner and Dr. Steve Oliver for providing me thoughtful comments on my study. Also, I want to thank Dr. Andrew Izsák for his support. Special thanks go to the participant of this study, Amy, who accepted to be a part of this study. I would like to thank the Ministry of National Education of the Republic of Turkey for supporting me financially during my study in the United States. Last but not least, I owe special thanks to the editor and the reviewers for their careful reading and invaluable suggestions on the manuscript.

\section{Copyrights}

The works published in e-Kafkas Journal of Educational Research are licensed under a Creative Commons Attribution-NonCommercial- 4.0 International License.

\section{Ethics Statement}

In this study, I declare that the rules stated in the "Higher Education Institutions Scientific Research and Publication Ethics Directive" are complied with and that we do not take any of the actions based on "Actions Against Scientific Research and Publication Ethics".

Ethics Committee Approval Information

The name of Ethics Committe: Institutional Review Board

The date of Ethich Committee Approval: 21.06.2018

Ethics Committee Approval Number: STUDY00006215 


\section{References}

Amador, J. M., Carter, I., Hudson, R. A. ve Galindo, E. (2017). Following a teacher's mathematical and scientific noticing across career progression from field experiences to classroom teaching. In Teacher noticing: Bridging and broadening perspectives, contexts, and frameworks (pp. 161-181). Cham: Springer.

Blömeke, S., Gustafsson, J. E. ve Shavelson, R. J. (2015a). Beyond dichotomies: Competence viewed as a continuum. Zeitschrift für Psychologie, 223(1), 3-13.

Callejo, M. L. ve Zapatera, A. (2017). Prospective primary teachers' noticing of students' understanding of pattern generalization. Journal of Mathematics Teacher Education, 20(4), 309-333.

Campbell, B. K. (2018). Toward more student-centered instruction: The advent of teacher noticing and responsiveness in mathematics and science education research. Journal of the William Mary Educational Review, 6(1), 24-38.

Choppin, J. (2011). The impact of professional noticing on teachers' adaptations of challenging tasks. Mathematical Thinking and Learning, 13(3), 175-197.

Didis, M. G., Erbas, A. K., Cetinkaya, B., Cakiroglu, E. ve Alacaci, C. (2016). Exploring prospective secondary mathematics teachers' interpretation of student thinking through analysing students' work in modelling. Mathematics Education Research Journal, 28(3), 349-378.

Dindyal, J., Schack, E.O., Choy, B.H. ve Sherin, M.G. (2021) Exploring the terrains of mathematics teacher noticing. ZDM Mathematics Education, 53, 1-16.

Dreher, A. ve Kuntze, S. (2015). Teachers' professional knowledge and noticing: The case of multiple representations in the mathematics classroom. Educational Studies in Mathematics, 88(1), 89114.

Dyer, E. B. ve Sherin, M. G. (2016). Instructional reasoning about interpretations of student thinking that supports responsive teaching in secondary mathematics. ZDM, 48(1-2), 69-82.

Fernández, C., Llinares, S. ve Valls, J. (2013). Primary school teacher's noticing of students' mathematical thinking in problem solving. The Mathematics Enthusiast, 10(1-2), 441-468.

Fisher, M. H., Thomas, J., Jong, C., Schack, E. O. ve Dueber, D. (2019). Comparing preservice teachers' professional noticing skills in elementary mathematics classrooms. School Science and Mathematics, 119(3), 142-149.

Fisher, M. H., Thomas, J., Schack, E. O., Jong, C. ve Tassell, J. (2018). Noticing numeracy now! Examining changes in preservice teachers' noticing, knowledge, and attitudes. Mathematics Education Research Journal, 30(2), 209-232.

Heinrichs, H. ve Kaiser, G. (2018). Diagnostic competence for dealing with students' errors: Fostering diagnostic competence in error situations. In T. Leuders, K. Philipp, \& J. Leuders (Eds.), Diagnostic competence of mathematics teachers (pp. 79-94). Cham: Springer.

Herppich, S., Praetorius, A. K., Förster, N., Glogger-Frey, I., Karst, K., Leutner, D., ... ve Südkamp, A. (2018). Teachers' assessment competence: Integrating knowledge-, process, and productoriented approaches into a competence-oriented conceptual model. Teaching and Teacher Education, 76, 181-193.

Hines, E. ve McMahon, M. T. (2005). Interpreting middle school students' proportional reasoning strategies: Observations from preservice teachers. School Science and Mathematics, 105(2), 88105.

Ingram, J. (2014). Supporting student teachers in developing and applying professional knowledge with videoed events. European Journal of Teacher Education, 37(1), 51-62.

Jacobs, V. R., Lamb, L. L. C. ve Philipp, R. A. (2010). Professional noticing of children's mathematical thinking. Journal for Research in Mathematics Education, 41(2), 169-202.

Jacobs, V. R. ve Empson, S. B. (2016). Responding to children's mathematical thinking in the moment: an emerging framework of teaching moves. ZDM, 48(1-2), 185-197.

Jakobsen, A., Ribeiro, C. M. ve Mellone, M. (2014). Norwegian prospective teachers' MKT when interpreting pupils' productions on a fraction task. Nordic Studies in Mathematics Education, 19(3-4), 135-150. 
Jong, C., Thomas, J. N., Fisher, M. H., Schack, E. O., Davis, M. A. ve Bickett, M. E. (2017). Decimal Dilemmas: Interpreting and Addressing Misconceptions. Ohio Journal of School Mathematics, 75(1), 13-20.

Kaiser, G., Busse, A., Hoth, J., König, J. ve Blömeke, S. (2015). About the complexities of video-based assessments: Theoretical and methodological approaches to overcoming shortcomings of research on teachers' competence. International Journal of Science and Mathematics Education, 13(2), 369-387.

Kersting, N. (2008). Using video clips of mathematics classroom instruction as item prompts to measure teachers' knowledge of teaching mathematics. Educational and Psychological Measurement, 68(5), 845-861.

Kilic, H. (2018). Pre-service Mathematics Teachers' Noticing Skills and Scaffolding Practices. International Journal of Science and Mathematics Education, 16(2), 377-400.

Kilic, H. ve Dogan, O. (2021) Preservice Mathematics Teachers' Noticing in Action and in Reflection. International Journal of Science and Mathematics Education, https://doi.org/10.1007/s10763-020-10141-2

Knievel, I., Lindmeier, A. M. ve Heinze, A. (2015). Beyond knowledge: Measuring primary teachers' subject-specific competences in and for teaching mathematics with items based on video vignettes. International Journal of Science and Mathematics Education, 13(2), 309-329.

König, J., Blömeke, S., Klein, P., Suhl, U., Busse, A. ve Kaiser, G. (2014). Is teachers' general pedagogical knowledge a premise for noticing and interpreting classroom situations? A videobased assessment approach. Teaching and Teacher Education, 38, 76-88.

Krupa, E. E., Huey, M., Lesseig, K., Casey, S. ve Monson, D. (2017). Investigating secondary preservice teacher noticing of students' mathematical thinking. In E. O. Schack, M. H. Fisher, \& J. Wilhelm, (Eds.), Teacher noticing: Bridging and broadening perspectives, contexts, and frameworks (pp. 49-72). Cham: Springer.

Louie, N. L. (2018). Culture and ideology in mathematics teacher noticing. Educational Studies in Mathematics, 97(1), 55-69.

Ma, L. (1999). Knowing and teaching elementary mathematics: Teachers' understanding of fundamental mathematics in China and the Unites States. Mahwah, NJ: Lawrence Erlbaum.

Magiera, M. T. ve Zambak, V. S. (2021). Prospective K-8 teachers' noticing of student justifications and generalizations in the context of analyzing written artifacts and video-records. International Journal of STEM Education, 8(1), 1-21.

Mason, J. (2002). Researching your own practice: The discipline of noticing. London: RouthledgeFalmer.

Mason, J. (2011). Noticing: Roots and branches. In M. G. Sherin, V. R. Jacobs, \& R. A. Philipp (Eds.), Mathematics teacher noticing: Seeing through teachers' eyes (pp. 35-50). New York: Routledge.

Maxwell, J. A. (1996) Qualitative research design: An interactive approach. Thousand Oaks, CA: Sage Publications.

McDuffie, A. R., Foote, M. Q., Bolson, C., Turner, E. E., Aguirre, J. M., Bartell, T. G., ... ve Land, T. (2014). Using video analysis to support prospective K-8 teachers' noticing of students' multiple mathematical knowledge bases. Journal of Mathematics Teacher Education, 17(3), 245-270.

Mitchell, R. N. ve Marin, K. A. (2015). Examining the use of a structured analysis framework to support prospective teacher noticing. Journal of Mathematics Teacher Education, 18(6), 551-575.

Nickerson, S. D., Lamb, L. ve LaRochelle, R. (2017). Challenges in measuring secondary mathematics teachers' professional noticing of students' mathematical thinking. In E. O. Schack, M. H. Fisher, \& J. Wilhelm, (Eds.), Teacher noticing: bridging and broadening perspectives, contexts, and frameworks (pp. 381-398). Cham: Springer.

Norton, A., McCloskey, A. ve Hudson, R. A. (2011). Prediction assessments: Using video-based predictions to assess prospective teachers' knowledge of students' mathematical thinking. Journal of Mathematics Teacher Education, 14(4), 305-325.

Osmanoglu, A., Isiksal, M. ve Koc, Y. (2015). Getting ready for the profession: Prospective teachers' noticing related to teacher actions. Australian Journal of Teacher Education, 40(2), 29-51. 
Phelps-Gregory, C. M. ve Spitzer, S. M. (2018). Developing prospective teachers' ability to diagnose evidence of student thinking: Replicating a classroom intervention. In T. Leuders, K. Philipp, \& J. Leuders, (Eds.), Diagnostic competence of mathematics teachers (pp. 223-240). Cham: Springer.

Santagata, R. ve Yeh, C. (2016). The role of perception, interpretation, and decision making in the development of beginning teachers' competence. ZDM, 48(1-2), 153-165.

Schack, E. O., Fisher, M. H., Thomas, J. N., Eisenhardt, S., Tassell, J. ve Yoder, M. (2013). Prospective elementary school teachers' professional noticing of children's early numeracy. Journal of Mathematics Teacher Education, 16(5), 379-397.

Sánchez-Matamoros, G., Fernández, C. ve Llinares, S. (2015). Developing preservice teachers' noticing of students' understanding of the derivative concept. International Journal of Science and Mathematics Education, 13(6), 1305-1329.

Sánchez-Matamoros, G., Fernández, C. ve Llinares, S. (2019). Relationships among prospective secondary mathematics teachers' skills of attending, interpreting and responding to students' understanding. Educational Studies in Mathematics, 100(1), 83-99.

Schäfer, S. ve Seidel, T. (2015). Noticing and reasoning of teaching and learning components by preservice teachers. Journal for Educational Research Online, 7(2), 34-58.

Scherrer, J. ve Stein, M. K. (2013). Effects of a coding intervention on what teachers learn to notice during whole-group discussion. Journal of Mathematics Teacher Education, 16(2), 105-124.

Sharpe, L., Hu, C., Crawford, L., Gopinathan, S., Khine, M. ve Moo, S. (2003). Enhancing multipoint desktop video conferencing (MDVC) with lesson video clips: Recent developments in preservice teaching practice in Singapore. Teaching and Teacher Education, 19(5), 529-541.

Shin, D. (2021) Preservice Mathematics Teachers' Selective Attention and Professional KnowledgeBased Reasoning About Students' Statistical Thinking. International Journal of Science and Mathematics Education, 19, 1037-1055.

Simpson, A. ve Haltiwanger, L. (2017). "This is the First Time I've Done This": Exploring secondary prospective mathematics teachers' noticing of students' mathematical thinking. Journal of Mathematics Teacher Education, 20(4), 335-355.

Smith, W. M., Beattie, H. L., Ren, L. ve Heaton, R. M. (2020). The evolution of a child study assignment: a potential approach to developing elementary mathematics teachers' professional noticing. Journal of Early Childhood Teacher Education, https://doi.org/10.1080/10901027.2020.1852346

Son, J. W. (2013). How preservice teachers interpret and respond to student errors: ratio and proportion in similar rectangles. Educational Studies in Mathematics, 84(1), 49-70.

Stahnke, R., Schueler, S. ve Roesken-Winter, B. (2016) Teachers' perception, interpretation, and decision-making: a systematic review of empirical mathematics education research. ZDM Mathematics Education, 48(1), 1-27.

Star, J. R. ve Strickland, S. K. (2008). Learning to observe: Using video to improve preservice mathematics teachers' ability to notice. Journal of Mathematics Teacher Education, 11(2), 107125.

Superfine, A. C., Fisher, A., Bragelman, J. ve Amador, J. M. (2017). Shifting perspectives on preservice teachers' noticing of children's mathematical thinking. In E. O. Schack, M. H. Fisher, \& J. Wilhelm, (Eds.), Teacher noticing: Bridging and broadening perspectives, contexts, and frameworks (pp. 409-426). Cham: Springer.

Patton, M. Q. (2015). Qualitative research and evaluation methods (3rd ed.). Thousand Oaks, CA: Sage. Tanışl1, D., Yavuzsoy Köse, N. ve Camci, F. (2017). Matematik Öğretmen Adaylarının Örüntüler Bağlamında Genelleme ve Doğrulama Bilgileri. Eğitimde Nitel Araştırmalar Dergisi, 5(3), 195222.

Teuscher, D., Leatham, K. R. ve Peterson, B. E. (2017). From a framework to a lens: Learning to notice student mathematical thinking. In E. O. Schack, M. H. Fisher, \& J. Wilhelm, (Eds.), Teacher noticing: Bridging and broadening perspectives, Contexts, and Frameworks (pp. 31-48). Cham: Springer.

Tunney, J. W. ve van Es, E. A. (2016). Using video for teacher-educator professional development. The New Educator, 12(1), 105-127. 
Ulusoy, F. (2016). Developing prospective mathematics teachers' knowledge for teaching quadrilaterals through a video case-based learning environment. Unpublished doctoral dissertation. Middle East Technical University, Ankara, Turkey.

Ulusoy, F. (2020). Prospective teachers' skills of attending, interpreting and responding to contentspecific characteristics of mathematics instruction in classroom videos. Teaching and Teacher Education, 94, https://doi.org/10.1016/j.tate.2020.103103

Ulusoy, F. ve Çakıroğlu, E. (2020). Exploring prospective teachers' noticing of students' understanding through micro-case videos. Journal of Mathematics Teacher Education, 24(3), 253-282.

van den Kieboom, L. A., Magiera, M. T. ve Moyer, J. C. (2017). Learning to notice student thinking about the equal sign: K-8 preservice teachers' experiences in a teacher preparation program. In E. O. Schack, M. H. Fisher, and J. Wilhelm, (Eds.), Teacher noticing: Bridging and broadening perspectives, contexts, and frameworks (pp. 49-72). Cham: Springer. 